Article

\title{
Servitization in Support of Sustainable Cities: What Are Steel's Contributions and Challenges?
}

\author{
Julian T. M. Pinto ${ }^{1,2,3, * \mathbb{D}}$, Manuel E. Morales ${ }^{2,4} \mathbb{D}^{\mathbb{D}}$, Mariia Fedoruk ${ }^{5}$, Marina Kovaleva ${ }^{6}$ and \\ Arnaud Diemer ${ }^{1,2}$ (D) \\ 1 European Commission's Horizon 2020 Programme, Marie Skłodowska Curie Fellowship Actions in \\ Excellent Research, AdaptEconII Project, Clermont-Ferrand 63000, France; diemera@aol.com \\ 2 Centre d'Etudes et de Recherches sur le Développement International (CERDI), \\ Université Clermont-Auvergne, Clermont-Ferrand 63000, France \\ 3 Department of Industrial Engineering, University of Iceland, Reykjavik 107, Iceland \\ 4 Industrial Bioeconomy Chair, NEOMA Business School, Campus Reims 51100, France; mrlalo9@hotmail.com \\ 5 Institute of Ecological Economics, Ukrainian National Forestry University, Lviv 79057, Ukraine; \\ fedoruk.mariia@gmail.com \\ 6 Department of Environmental Management, American University of Central Asia, Bishkek 79057, \\ Kyrgyzstan; m.kovaleva@auca.kg \\ * Correspondence: julian.torres@live.it
}

Received: 3 January 2019; Accepted: 31 January 2019; Published: 7 February 2019

check for updates

\begin{abstract}
In the pursuit of eco-efficiency, resilience, and self-sufficiency, sustainable cities focus on long-term environmental goals instead of only short-term economic ones. To do so, many of them rely on servitization, the practice of replacing tangible solutions for intangible ones. Considering steel's wide range of applications and its pervasive presence, this article's goal was twofold: Not only to understand how servitization helps sustainable cities, but also the contributions and challenges of the steel present in service-providing. To do so, the criteria of sustainable urban metabolism and circles of sustainability were used to analyze three case studies of servitization: energy, housing, and mobility. The results showed that servitization can provide significant benefits to sustainable cities, while also being able to substantially alter the supply-side dynamics of steelmaking by affecting, most notably, demand. This brought to light how important it is for steelmakers to pay close attention to the service-providing initiatives that may concern their clients and products. Nevertheless, further research is necessary to fully understand all of the effects that servitization can have on all of the commodities involved in its implementation.
\end{abstract}

Keywords: servitization; sustainable cities; steel; circles of sustainability; sustainable urban metabolism

\section{Introduction}

A healthy environment, social cohesion, and economic efficiency are trademarks of a sustainable city, a political entity that defies market dynamics by prioritizing long-term political goals instead of short-term economic ones, focusing on eco-efficiency, self-sufficiency, and circular environmental management [1-5]. One of the tools available for sustainable cities and the industries within it to manage their resources is servitization: The practice of reducing material needs by changing a product's ownership or its presence altogether in favor of providing a service or solution [6-8].

Although certain forms of servitization (e.g., public transportation, vehicle rentals, shared housing) can already be seen in most modern societies, most research efforts are dedicated to implementing the services themselves on the demand-side, and not to further understanding their effects on the supply-side of the materials and resources involved [6,9]. Although innumerable materials are part of a society's metabolism, this article focuses on steel, one of the most prevalent commodities that, as 
present it may be, has its supply chain often dismissed along with that of other primary and secondary materials when focus is given to service-providing alone [7].

In order to better understand the potential contributions of steel and the challenges it faces when interacting with servitization to help improve urban sustainability, this article used two tools-sustainable urban metabolism and circles of sustainability-and supporting bibliography to quantitatively and qualitatively analyze three case studies that exemplify successful applications of servitization.

\subsection{Sustainable Cities: Cells of a Larger Organism}

The historic conceptual evolution of sustainable cities was based on that of sustainable development-a term that later gained political connotations with the Brundtland Commission —and which can be traced back to 18 th century forestry management in Germany $[3,5,10]$. In the report Our Common Future, sustainable development was defined as development that meets the needs of the present without compromising the ability of future generations to meet their own needs [11]. At that time, the idea of a "sustainable city" was an automatic derivative related to urban development policies.

By the 90's it was fleshed out in the Aalborg Charter [12] by more than 700 cities worldwide, and in the Melbourne Principles of the Local Agenda 21 [13]. From then on, the concept of a sustainable city grew and, in practice, became strongly intertwined with the idea of a triple bottom line-or three pillars-denoting a close relationship between economic, social, and environmental sustainability, with a combination of indicators to measure each of them $[3,5,14]$.

Meadows [15] and Brugmann [16] approached the term from a more environmentally-oriented perspective and proposed that it should include indicators for pollution and carbon emissions, water consumption and quality, energy mix and demand, waste management, green built environment, and forest and agricultural land management. Burdett and Sudjic [17], on the other hand, adopted a more socio-economic interpretation, in which social equity alongside a greener living environment should be considered for the development of sustainable cities, also suggesting that cities should offer proximity, density, and variety enough to engender productivity benefits for firms and help stimulate innovation and job creation.

The overall mindset began to change at the beginning of the 21st century when Rogers [18] conceptualized a sustainable city as a place where a higher quality of life is realized in tandem with policies which effectively reduce the demand for resources and draw from the city's hinterland to become a more self-sufficient and cohesive economic, social, and environmental unit or ecosystem. As autonomous as a cell can be, a sustainable city is unable to live fully independently outside the organism of its nation; therefore, renewed attention was then given to some of the economic aspects of sustainable cities, rekindling the academic interest in contributing to policy-making, notably on the transitional and structural measures necessary to shift the interactions between urban stakeholders, from linear and production-oriented to circular and service-oriented ones [5,19].

Keeping in mind that the urban-level approach of sustainable cities provides tangible applications, easier implementation, and reduced monitoring complexity, when compared to approaches in regional or national scales all the while supporting their results as well [3-5], the next section of this article introduces one of the tools capable of contributing to resource efficiency and management bottom-up.

\subsection{Servitization: Demand-Side Circularity from Within}

The term servitization was created to describe the idea of product manufacturers, wholesalers, and retailers reducing their tangible portfolio in favor of an intangible one [20,21]. Currently, the application of this concept is closer to its origin in the 1980s, in which the idea was to deliver to the customers a package of services, goods, support, and knowledge that together represent a solution, and not only a sale $[7,22,23]$. Most modern companies adopt it in either the stages of pre-sale (e.g., trials, demonstrations, and custom design); sale (e.g., installation and training); or post-sale (e.g., maintenance, support, and warranty) [24,25]. 
Nevertheless, actual reductions in the overall amounts of resources and energy consumed usually derive from services that actually shift product ownership or that do not require the customer to acquire the product in the first place, instead of buying the results or benefits it delivers (e.g. leasing, renting, and pooling) [26,27]. In $2009,84.8 \%$ of manufacturing companies offered services to support their products, being only $12.1 \%$ of those directly related to the changing product ownership or to a product being operated by the manufacturer as a service to the customer [28,29].

Although well aligned with concomitantly developing concepts, such as circular economy, the servitization trend evolved in parallel and gained its largest share of attention after the photocopier industry decided to lease or rent their multifunctional products to foster a pay-per-printed-page solution, instead of a one-photocopier-per-office business model [20]. Once customers started perceiving direct or indirect financial benefits, this phenomenon opened the doors for discussions in all related matters: From the potential innovations in business models to the psychology of product ownership; from unique selling propositions (USPs) to sustainable resource management and product-service systems (PSS) [23,30,31].

Service-providing initiatives then became commonplace in marketing management, focusing almost exclusively on the costs being reduced in the search for profit, while giving little to no attention to the resources being saved $[9,32]$. Although headed in the right direction from an environmental standpoint, this counterintuitively went against some of the principles of sustainability: Selling services without addressing their resource demands ended up, in some cases, increasing material consumption $[6,8]$. It was when academics, involved in what is called redistribution and sharing within the circular economy framework drove their attention to service-providing practices already in place that servitization found new grounds and began receiving more support as a means to retain resources longer in the economy, creating value from service and circularity instead of value from natural resource extraction and transformation $[9,33,34]$.

Although the variety of resources that circulate within a given society can be theoretically infinite, this article focuses on steel, a commodity with significantly different dynamics from those of the service sector, but that nonetheless counts on plenty of intersections with servitization applications.

\subsection{The Role of a Commodity in a Service Economy}

Steel is a key commodity in global economies, continuously increasing in use per capita-steadily from $204.6 \mathrm{~kg}$ in 2011 to $214.5 \mathrm{~kg}$ in 2018 — due to its wide range of applications: From home appliances to cargo hauling, from construction to telecommunications [35-37]. Steel's life cycle starts when iron ore is mined and it ends either within built structures with long lifespans or by being recycled as scrap, most of its environmental impacts being related to the use of non-renewable energy sources and the consequent effects on the climate [38-40].

The steel industry alone is responsible for approximately $6.5 \%$ of worldwide $\mathrm{CO}_{2}$ emissions [41] and it consumes substantial amounts of coal, as seen in Figure 1. In order to achieve the Sustainable Development Goals (SDGs), it is estimated that the steel industry worldwide would need to increase the use of electricity from the current $26 \%$ to $40 \%$ by 2030 [42].

Notably in the last decade; however, the steel industry has been facing difficulties regarding prices, energy, trading, and competitiveness - all understood to be hindering environmental progress regarding emissions and resource efficiency [43]. Consequently, multiple academic, institutional, governmental, and industrial experts have highlighted the need for this industry to have an active role in expanding and improving end-of-life markets, mostly to increase production based on steel scrap to support a transition towards the use of electricity instead of coal [43].

Due to the its products' and its raw materials' physical and chemical characteristics and requirements, the steel industry has traditionally given substantial attention to variables that boost or hinder the quality, quantity, and profitability of its outputs, being one the pioneering industries to apply some of the environmental principles of circular economy and sustainable development-mainly recycling and by-product reuse $[43,44]$. 


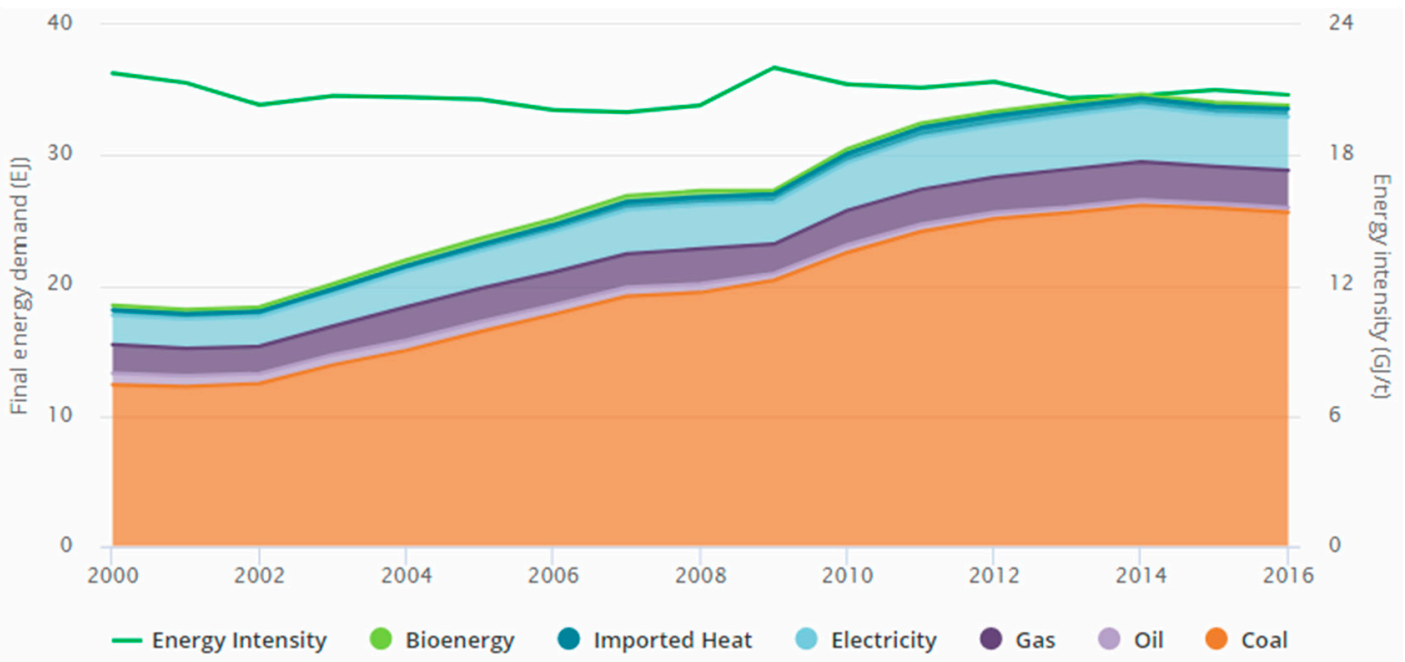

Figure 1. Steel's energy intensity and demand [42].

As important as recycling is-capable of saving $1400 \mathrm{~kg}$ of iron ore, $720 \mathrm{~kg}$ of coking coal, and $120 \mathrm{~kg}$ of limestone per ton of recycled scrap, on a global average - and even though record-breaking sums of capital have been directed towards environmental goals, minimal attention has been given to redistribution, sharing, or servitization, despite $65 \%$ to $80 \%$ of investments being focused on end-of-life solutions [43,45-49]. And policy wise, regardless of how significant the results of servitization, sharing, or redistribution have been when implemented [44,50], no examples of direct policy-based stimulus or guidance has been found by the authors to support service-based practices capable of allowing this industry to contribute to the sustainability of an urban environment.

It was with this context in mind that the authors chose this material as the object of exploration for better understanding how servitization can affect the supply-side dynamics of sustainable cities and; therefore, contribute to environmental progress. In the aforementioned photocopier example alone, the reduction in total demand for the specific steel components necessary for these machines to operate configures, in itself, a fitting argument for how servitization can be a tool for reducing natural resource exploitation when its effects are passed along the steelmaking supply chain.

Along with the other commodities present within the goods potentially targeted by servitization, steel's presence in service-oriented projects would be, even if indirectly, a factor capable of affecting, for example, (a) the importance of steel products' quality and durability; (b) the quantities, quality, and accessibility of recyclable scrap; (c) the development of other end-of-life and circularity services such as repair, maintenance, reuse, sharing, refurbishment, and remanufacture; and (d) the gradual shift towards operational longevity instead of component replacement, counteracting trends of planned and designed obsolescence.

\section{Methodology}

This article aims to understand the potential contributions that steel could bring through servitization to a sustainable city as well as the challenges steel could face while attempting to do so. This study's contributions derive mostly from approaching the potential benefits of servitization to a sustainable city from the supply-side perspective, focusing on how such a commodity's supply chain operation could improve in order to better support, through service-providing, the environmental aspects of an urban metabolism.

The first step taken was evaluating and analyzing what were the contributions that three successful case studies on servitization would provide to a sustainable city; then, steel's participation was identified within each of the case studies and its respective contributions and challenges were discussed. 


\subsection{Tools}

Assessing the behaviors, performance, or structure of sustainable cities is a task that can be carried out by substantially different approaches, methods, and tools. Given this article's focus on servitization and on the steel within it, the authors opted for the ex post use of two tools: a quantitative one (sustainable urban metabolism) and a qualitative one (circles of sustainability).

As detailed next, these tools were chosen based on their different approaches to stakeholders' involvement, eco-services, and eco-efficiency. While the first one provides quantitative support for decision- and policy-making based on urban ecosystems theory, the second one is intended to be flexible and modular in order to align empirical solutions to the social conditions that permeate them $[18,51,52]$.

\subsubsection{Sustainable Urban Metabolism}

The underlying principle of urban metabolism is the conservation of mass towards the transformation of industrial activities in an urban environment, from what is largely known as non-sustainable and linear systems to what would resemble sustainable and circular ones [51]. As seen in Figure 2, it begins by employing material and energy flow analysis (MFA and EFA, respectively) for the identification and quantification of material and energy usage, as well as assessing their impacts on the environment [53].

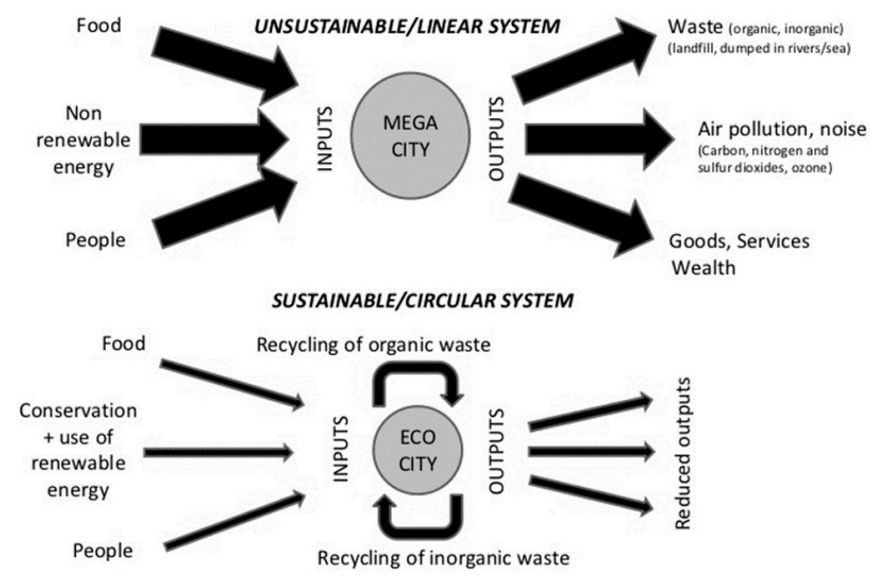

Figure 2. The city as a system [52].

This metabolic assessment takes into account the basic consumption of the households within a city-such as heat, electricity, water, and food-and links them to the local means of production that have corresponding benefits in terms of local economy, employment, greenhouse gas reduction, etc. Depending on the intensity of the flows of each resource and on how they evolve through time, the urban metabolism can gradually shift to patterns of zero waste, positive energy, closed water cycles, etc. $[18,54]$.

From that point on, having a clearer holistic and systemic understanding of a city's metabolism, measures for delivering improvements to each of the subsections of the assessment become the focus [18]. Finding ways to balance inputs and outputs among the multiple stakeholders involved naturally includes social and economic aspects, thus stimulating the development of new technologies and business models capable of reducing stocks and improving circularity, without negatively affecting quality of life and wellbeing [18,54].

This article's use of this tool considers the before and after conditions of inputs, outputs, stocks, and flows in the context of each case study, aiming to identify how each case study was able to affect sustainability by empirically altering the amount of materials or energy present in the urban environment they were a part of. 
To do so, the initial and final amounts of steel embedded in the servitization solutions deployed by each case study, as well as the energy used to produce it, were identified and calculated and, based on their sources, flows, stocks, and sinks, evaluated regarding their effects on sustainability along with the next tool.

\subsubsection{Circles of Sustainability}

Circles of sustainability, on the other hand, focuses less on quantitative and more on qualitative aspects of a city's metabolism. Although it encompasses environment and economy for the purposes of flow optimization, its main attributes are the intersections it provides with social conditions such as resilience, cooperation, and proximity within a community [52,54]. This tool is intended to be flexible and modular, and addresses the four domains of ecology, economics, politics, and culture by dividing them each into seven key aspects, all with their own criteria for conducting discrete semi-directed interviews with key actors and stakeholders of a city, resulting in the nine-points scale of seen in Figure $3[52,54]$.

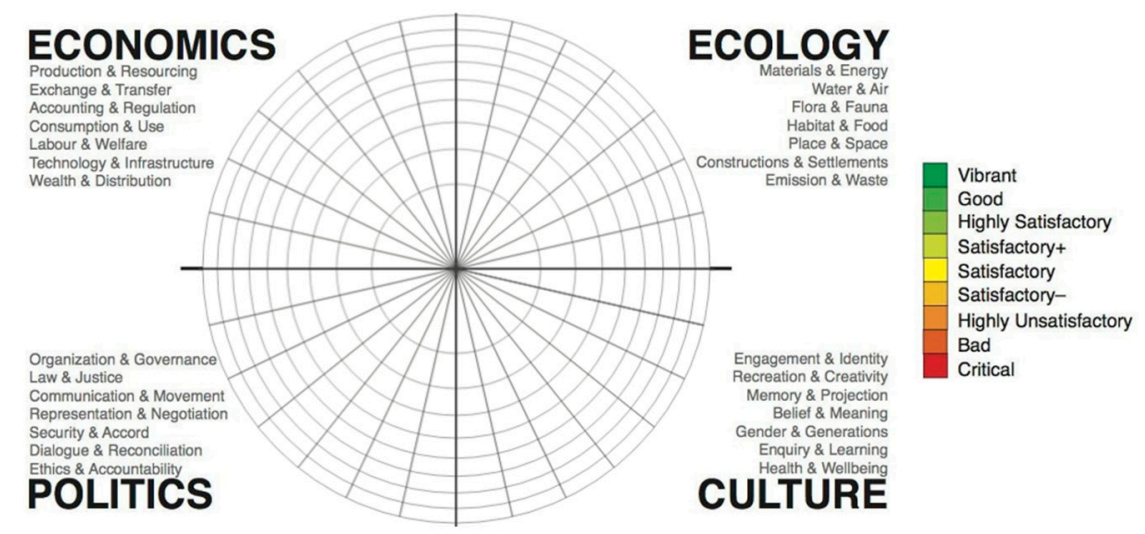

Figure 3. Circles of sustainability [52].

Multiple cities (e.g., Melbourne, Porto Alegre, Milwaukee, and New Delhi) have assessed their sustainability using this tool, enabling not only a diagnostic understanding of their situation, but also the intake of feedback and knowledge from the participation of their industries, communities, and decision-makers [55]. In Johannesburg, it helped its Department of Transportation to redefine public mobility goals; in Port Moresby, it helped the municipality in finding new solutions to land use management issues concerning informal employment and ethnical disputes; and in Valetta, it improved the understanding of the cultural obstacles and political barriers responsible for hindering the development of an educational system to be capable of retaining qualified workforce [55].

In this article, this tool was used to identify where within the domains of a sustainable city each case study's contribution would help improve sustainability and, in conjunction with the previous tool, to which extent these effects were linked or not to the presence of steel. Whenever and wherever steel's presence was identified within the domains of a sustainable city as per each case study, and having already applied the previous tool for identifying and measuring the quantitative aspects of steel's participation in each case study, the authors then used the criteria of circles of sustainability to evaluate how impactful the quantitative changes in steel would be to the qualitative aspects of sustainability.

\subsection{Case Studies}

Three case studies, focusing on different applications of servitization principles, were chosen for this study: energy [56], housing [57], and mobility [58]. All case studies are described below and have four aspects in common: (a) Being based on real life applications; (b) seeking benefits and improvements from an environmental and sustainability perspective; (c) considering the policy and social factors of the context in which they are inserted; and (d) discussing their results not 
only in present terms, but also in perspectives for future contributions. The authors believe each of the case studies illustrates a different role that steel can play when servitization is used towards improving sustainability.

\subsubsection{Energy}

In an urban environment, electricity not only supplies industrial and commercial activities, but also guarantees particular levels of provision, such as lighting, room temperatures, and humidity control [59]. Servitization in energy is; therefore, a conjunction of energy supply and energy-related services aiming at efficiency, savings, and sustainability [60-62]. It can also refer to outsourcing and decentralization processes, involving third-party contractors for distribution and maintenance or even the deployment of energy generation technologies directly onto a customer's property, often creating potential for energy feedback to either grid or supplier $[63,64]$.

A good example of decentralization based on electricity feedback to the grid was developed by Pinto et al. [56], in which photovoltaic solar panels installed on the roof of houses of a social program were shown not only capable of creating energetic independence for home owners facing a structural national crisis, but also of reducing overall generation demand due to the creation of localized electricity feedback networks when given proper policy support.

The study considered three different electricity consumption scenarios for houses in five different regions of Brazil, keeping in mind specific solar irradiations, quantity of panels, costs of deployment, generation potential, and sensitivity analysis. Results indicated monthly bill savings between $8 \%$ and $52 \%$ per house, with potential electricity feedback to the grid up to $47 \%$ under adequate policy support [56].

\subsubsection{Housing}

Developing sustainable housing is an essential component of sustainable cities, not only because globally over one-third of all final energy and half of electricity are consumed by housing and generates approximately one-third of global carbon emissions [65], but also because multiple aspects of housing directly affect inhabitants' health, comfort, wellbeing, quality of life, and workforce productivity [66]. Sustainable housing is designed, constructed, operated, renovated, and disposed of in accordance with ecological principles for the purposes of minimizing the environmental impact and promoting occupants' health and resource efficiency [67].

Although retrofitting (i.e., upgrading existing buildings to improve their energy efficiency and decrease emissions of greenhouse gasses) seems to be technically viable and sometimes economically attractive, multiple barriers prevent optimal applications [68,69]. Servitization of sustainable housing takes into account the entire life cycle of a building in an attempt to re-use, recycle, and upcycle by means of, for example, the adoption of design-for-disassembly of individual parts and components that need to be fixed or replaced.

In their study, Céron-Palma et al. [57] focused on the operation stage of a house (i.e., while citizens inhabit the building), proposing measures to reduce emissions linked to energy consumption and to decrease food dependence with the subsidized replacement of standard appliances with eco-efficient alternatives and by creating green spaces and productive gardens. The study collected consumption data to feed a Life Cycle Analysis model that encompassed all operational aspects of living in that environment in Merida, Mexico (e.g., products' packaging, and material logistics).

After testing six different scenarios, results indicated that replacing appliances with more eco-efficient alternatives and making use of a green space or garden for food cultivation could save an average of 1 ton of $\mathrm{CO}_{2}$ eq emissions every year per house (i.e., $67 \%$ less emissions than a standard Mexican home) [57]. 


\subsubsection{Mobility}

The transport sector consumes 2.2 billion tons of oil equivalent, accounting for about $19 \%$ of global energy demand and for $24.3 \%$ of the greenhouse gas emissions [70]. Consumption is expected to increase by between $80 \%$ and $130 \%$ above today's level until 2030 and, unlike other sectors-which decreased their emissions by circa 15\% between 1990 and 2007-transportation increased it by 36\% during the same period [70].

Servitization in transportation contributes the most to sustainable cities in terms of sustainable urban mobility (SUM), a transport model that stimulates interaction among all involved stakeholders in order to develop a comprehensive mobility service offer that responds to citizens' needs for flexibility and convenience, door-to-door, removing the need for vehicle ownership by combining different shares of, for example, public transportation, car-sharing, taxis and shared taxis, bicycle and bike-sharing, car-pooling, or park-and-ride [71,72].

Diez et al. [58] focused on the city of Burgos, Spain, in which fifteen different measures were put in place in 2005 by a CiViTaS project initiative. Measures included (a) switching public transportation to biodiesel; (b) increasing the amount of pedestrian-preferential areas; (c) underground parking areas; (d) higher capacity public transportation vehicles; (e) schedule alignment between different transportation methods; (f) bicycle lanes, rentals, parking, and bike-sharing; and (g) restrictions on heavy load traffic.

The city saw multiple positive results in the span of five years, mostly related to citizen behavior transition towards bicycles and public transportation instead of private vehicles [58]. When considering a twenty-year period, up to 47,000 tons of $\mathrm{CO}_{2}$ eq emissions were expected to be avoided at the expense of $€ 7.2$ million in investments, well within estimations of European authorities for funding similar projects [58].

\section{Results}

This section presents the knowledge acquired from evaluating and analyzing each servitization application towards the improvement of sustainability in an urban environment. Each case study was subjected to ex post application of the tools described before and their key attributes were identified along with steel's contributions and challenges.

\subsection{Energy}

The servitization of electricity once bought as a product and delivered to a household merely for consumption into a localized and demand-specific solution, capable of reducing costs and adding consumer value, as seen in the study by Pinto et al. [56], relied on two different factors: (a) Replacing a mostly hydraulic-based grid electricity supply with decentralized solar sources, and (b) retaining, redistributing and reusing excess energy within the local network by using feedback. The first factor contributes to reducing electricity demand from the installed capacity while reducing the demand for electricity distribution along the grid. On the other hand, the second factor not only contributes to the previous one, while providing economic benefits to the citizen, but also adds intangible values such as grid independence, community integration, and participation.

From the perspective of sustainable urban metabolism, the propositions of Pinto et al. [56] help to partially transfer electricity sourcing from outside a city's boundaries to the households within it, directly reducing the required external energy input while strengthening and empowering local stakeholders at the expense of an increase in material stock within the city's boundaries. Furthermore, it reduces the amount of electricity wasted by over-generation as well as electricity lost during long range distribution. Cities in which such a project would be deployed would become altogether more resilient and sustainable while helping reduce emissions, losses, and wastes related to electricity generation.

When applying the criteria of circles of sustainability to this case study, several contributions were identified, as seen in Figure 4. In the domains of politics and culture, minor benefits to "Organization \& 
Governance" and "Engagement \& Identity" were perceived, related to the required policy adjustments that would enable grid feedback and feed-in tariffs and to the creation of a local community of households of which roofs now include solar panels, respectively.

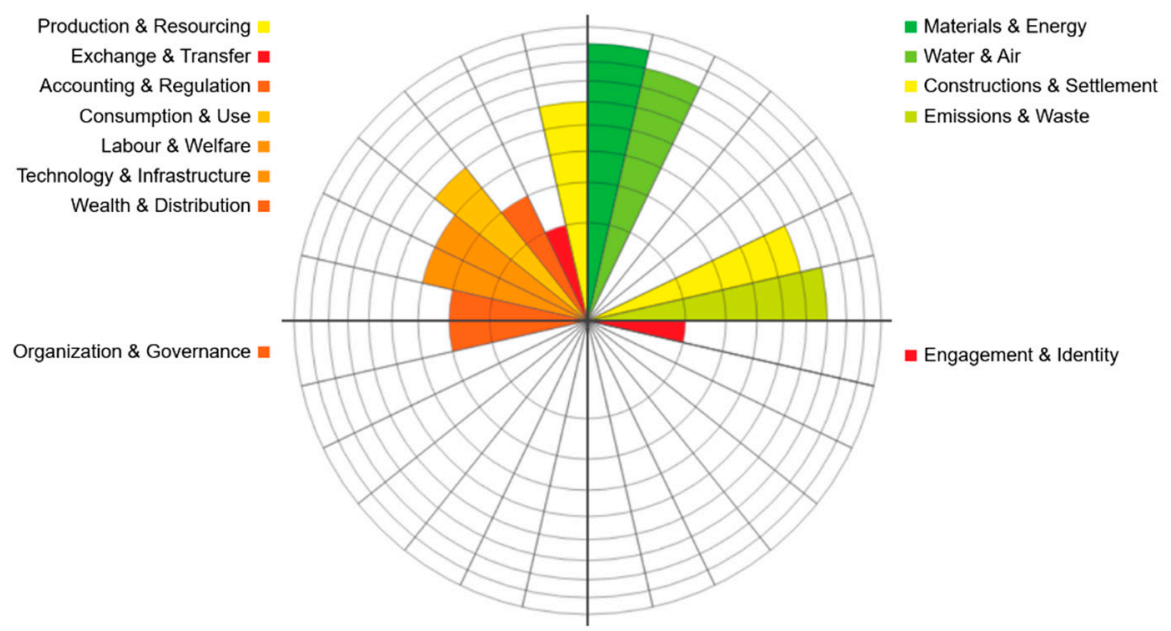

Figure 4. Energy case's perceived key contributions to sustainability.

It was in the ecology and economy domains; however, that most contributions were perceived. Deploying photovoltaic solar panels onto the roofs of Brazilian households could significantly shift how electricity is used and consumed in relation to the existing matrix, potentially creating new service sector jobs related to installation and maintenance. Moreover, improving infrastructure by using new technologies is a good way to increase local wealth distribution, while promoting or changing how knowledge and capital are exchanged. Additionally, having a network capable of grid feedback also increases the need for proper and engaged accounting and regulation, especially if the study's proposition of feed-in tariff cross-discounts is put in force.

Changing how electricity is generated also changes the materials necessary for the equipment used to generate it. Photovoltaic solar panels use considerably more silicon than iron in their composition, for example, in addition to other materials less pollutant to produce or less impactful to implement than hydraulic energy infrastructure. Consequently, both direct and indirect benefits to air quality, water quality, and reductions in the amounts of emissions and waste generated would be perceived throughout the entire system, thus improving the sustainability of the urban area it would be a part of, while potentially reducing the need for environmental impacts outside its boundaries as well.

Although steel presence in photovoltaic solar panels is minimal-around 3\%, in the frame and in the installation hardware, consisting mostly of stainless alloys UNS S30400 and S31600 [73]—it is important to note that the mainly hydraulic Brazilian energy matrix relies heavily on energy generation equipment made of steel and, even if the distribution itself depends mostly on copper and aluminum, steel-intensive machinery and structures are always present [74-78].

The results available in the study by Pinto et al. [56] point to an average of $153.25 \mathrm{GWh}$ generated by 405,691 solar panels installed onto the roofs of 73,762 houses, the equivalent of the entire electricity generation capacity of the Jupiá hydropower plant in Três Lagoas, Brazil [75]. Considering that an average hydropower plant contains 10,000 tons of steel in its structure [74] and taking into account an average photovoltaic solar panel mass of $18 \mathrm{~kg}[76,78]$, the participation of the steel present in the solar panels is about $0.7 \mathrm{kWh} / \mathrm{kg}$ of steel, while the participation of the steel present in the hydropower plant would be of approximately $0.015 \mathrm{kWh} / \mathrm{kg}$ of steel— 45 times less.

It is important to note; however, that solar panels cannot produce electricity $24 \mathrm{~h} /$ day, thus requiring either energy storage or additional energy sources to fully supply the demands of a household. Considering the use of lithium ion batteries and only $10 \mathrm{~h} /$ day of solar irradiation, the previous result 
in the participation of steel in electricity generation falls to $0.24 \mathrm{kWh} / \mathrm{kg}$-still 16 times better than hydropower alone for a period of 30 years of operation.

Furthermore, considering an energy intensity of $22.5 \mathrm{GJ} /$ ton of steel [79], producing all the solar panels and the required amount of batteries for this case study would consume approximately $5.35 \mathrm{TJ}$, while building the equivalent hydropower plant would require around $225 \mathrm{TJ}$ for steel alone, with the notable addition of stronger and more complex alloys such as UNS S32205 and S17400 [73].

This indirect reduction in supply-side steel intensity per $\mathrm{kWh}$ generated, coming as a result of demand-side servitization, points to one of the potential contributions of steel-in this case related to its quantity; although less steel is present, its participation is substantially more relevant. The challenge for steel, in cases like this, resides mostly in identifying where is the least amount of steel capable of providing the most environmental benefits (e.g., small amounts on a solar panel provide more environmental value than very large amounts in a hydropower plant).

\subsection{Housing}

By subsidizing a transition towards eco-efficiency within households and supporting it with maintenance-whether if by leasing or not-a city can turn appliances, previously acquired by its citizens merely as products to be used and discarded, into solutions capable of actively supporting the reduction of its required energy inputs as well as its emissions. Servicing this equipment and further supporting this initiative with the creation of green spaces and gardens capable of providing food, and consequently reducing the amounts of packaging, food waste, and transportation, poses as a solid contribution to sustainability.

As per sustainable urban metabolism, the study from Céron-Palma et al. [57] contributes to reducing inputs and outputs, but minimally—if at all—to reducing stocks. The reduction of inputs derives mostly from the green spaces and gardens producing food and avoiding the need for packaging and transportation, while the reductions in outputs are most expressive regarding the energy savings provided by eco-efficient appliances and the consequent reduction in emissions. Céron-Palma et al. [57] also present the possibility of carbon sequestration in the green spaces and gardens, but with almost negligible effects relative to the other benefits.

Although the amount of materials and food in stock would likely be unaffected, "Use \& Consumption" patterns would change and, consequently, so would "Production \& Resourcing", as per the criteria of circles of sustainability. As summarized in Figure 5, minor effects on most of the aspects of the economic and political domains would nevertheless provide substantial improvements in the ecology domain. These improvements would be directly related to increases in health and wellbeing, while contributing - even if marginally - to the creation of a locally-engaged community.

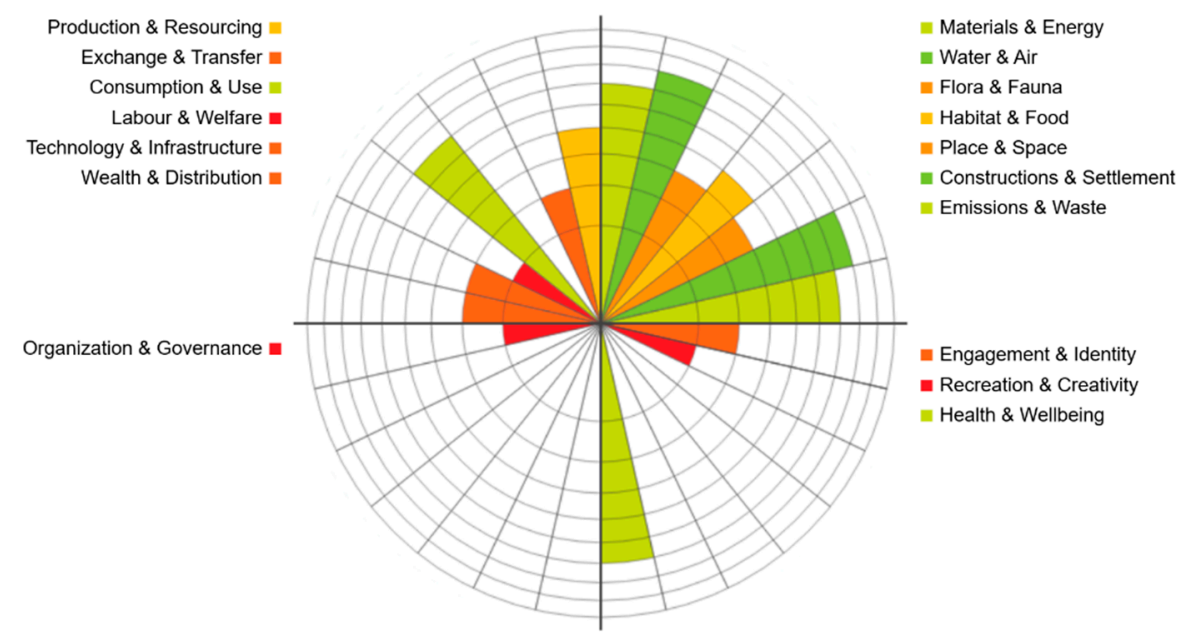

Figure 5. Housing case's perceived key contributions to sustainability. 
The intersections that exist between all of the aspects of the ecology domain ended up boosting each other; therefore, increasing environmental quality. This points to a reinforcing behavior which, whether intended or not by Céron-Palma et al. [57], presents major long-term sustainability and resilience benefits; the less issues with emission and wastes, the better water and air quality, which by itself helps improve "Flora \& Fauna" and "Habitat \& Food", even if marginally in the short-term. Finally, "Place \& Space" improve as well, further boosting health and wellbeing and fostering engagement and identity within the local community, effects of which feed back to the beginning.

As interesting as this behavior may be, its impacts on emissions are less substantial than those of the eco-efficient appliances, highlighting the importance of both being deployed in tandem. Since steel is not present in the green spaces and gardens, and that the case study does not specify which are the types of food produced therein, nor if those are traditionally contained in steel cans and other steel containers, focus was given to the eco-efficient appliances when addressing the participation of steel in emissions. All other variables of the case study's life cycle analysis were assumed unchanged, meaning eco-efficiency had no effect on the amount of steel content of each appliance. This choice was made due to the theoretical infinite number of possibilities by which eco-efficiency can be achieved by different manufacturers in different models of each appliance.

According to the results from Céron-Palma et al. [57], replacing standard appliances with more eco-efficient ones reduced energy consumption by approximately $46 \%$. Considering an average steel content of $60 \%$ per $140 \mathrm{~kg}$ refrigerator, $35 \%$ per $76 \mathrm{~kg}$ washing machine, and $46 \%$ per $37 \mathrm{~kg}$ air conditioning unit [80-84], the calculations showed that steel's participation in annual emissions per house was reduced by $32 \%$ on average, as a result of changing to eco-efficient appliances. More specifically from 4.90 to $3.35 \mathrm{kgCO}_{2} \mathrm{eq} / \mathrm{kg}$ of steel (refrigerator), from 1.90 to $1.30 \mathrm{kgCO}_{2} \mathrm{eq} / \mathrm{kg}$ of steel (washing machine), and from 84.67 to $57.76 \mathrm{kgCO}_{2} \mathrm{eq} / \mathrm{kg}$ of steel (air conditioning unit).

These results grow in significance when keeping in mind the case study's scope of 112,000 houses, resulting in the same $322 \mathrm{TJ}$ to produce all the steel involved, generating $176.74 \mathrm{Mt}$ of $\mathrm{CO}_{2}$ eq emissions, instead of $259.06 \mathrm{Mt}$. In this case, even though the amount of steel per appliance and the energy used to produce it remained the same, steel's contribution would not reside in its quantity, but in the type of steel and in how it is used in an appliance, for example, towards improving its eco-efficiency during the use phase.

Although this demand-side servitization initiative has minor effect on supply-side scale, the steelmakers' challenge would be to decide on which type of steel to produce (e.g., alloys with better electrical conductivity) and how to ensure its optimal use in a product. Traditional use of steel in appliances revolves mostly around stainless or tool steels used in motors and structural segments, such as UNS S30400 and S43000. In eco-efficient appliances, steel use would tend to revolve more around electrical and tool steels similar to those present in electronics [73], thus changing the alloying requirements of production.

\subsection{Mobility}

After five years of the implementation of the CiViTaS project in the city of Burgos, a clear change in its citizens' mobility behavior was noticed: It successfully stimulated approximately $10 \%$ of its population to transition from either walking or owning a private car towards using either more public transportation, bicycles, or lighter vehicles such as motorcycles [58]. Considering bicycles and, notably, public transportation were provided as a service by the city for the population, and that these means of transportation are less-if at all-pollutant in comparison to cars, servitization has proven itself environmentally friendly once again.

Even considering an increase of $1 \%$ in the use of motorcycles and a $6 \%$ reduction in the amount of people who preferred to walk their commutes, emission results were very favorable, pointing towards a successful mobility solution proposition that positively affects urban environment. Keeping in mind that bicycles now have their dedicated lanes, and that buses and motorcycles contribute 
to reducing overall traffic in comparison to cars, this mobility solution also presents medium- to long-term sustainability benefits.

Using the criteria of sustainable urban metabolism, it is possible to identify that the study conducted by Diez et al. [58] altered the city's inputs and stocks, by affecting the composition of the city's mass balance due to the different types of vehicles being used. Consequently, the flows related to mobility and transportation are rendered more efficient, still overshadowed; however, by the notable effects that takes place among the outputs. By changing the mobility matrix, not only do different materials become part of the urban system, but also different and more sustainable sources of energy gain traction: Less cars meant that gasoline and diesel gave way to buses' biodiesel, for example.

With less of their income being used to own a car, "Wealth \& Distribution" improved from the citizens' perspective, as per the criteria of circles of sustainability, as seen in Figure 6. Improving aspects of the political domain related to organization and communication would not only drive use and consumption towards a more sustainable behavior, but also help shift production and sourcing, thus promoting the exchange and transfer of more sustainable knowledge and goods. And even if improvements to technology and infrastructure would be minor, the increase in transportation services would require more jobs related to operation and maintenance instead of those related to the replacement of car parts and components.

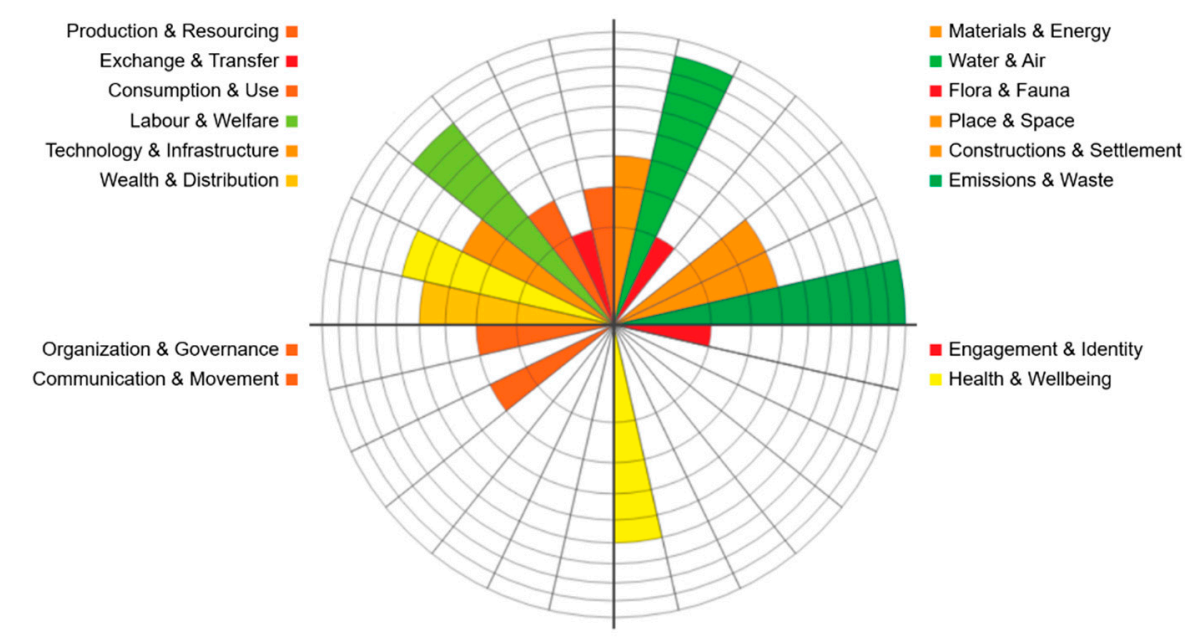

Figure 6. Mobility case's perceived key contributions to sustainability.

The key contributions, nevertheless, are present in the ecology domain: Measures that help reduce traffic - which relate to "Construction \& Settlement" - further help reduce emissions and contribute to citizens' perception of place and space, due to better water and air quality, altogether boosting health and wellbeing in the culture domain as well. Therefore, this study configures a good example of sustainable urban mobility, well aligned with the idea of a sustainable urban metabolism.

Having changed which vehicles are used and the frequency of their usage, the study indirectly changed how steel is present in the city as well. Considering that cars, buses, bicycles, and motorcycles are built with different types of steel in different amounts—on average $900 \mathrm{~kg}, 6,000 \mathrm{~kg}, 6 \mathrm{~kg}$, and $70 \mathrm{~kg}$, respectively [85-87] —not only do the total amounts of steel change, but also their participation in the emissions that occur as a consequence of their presence.

Although using more buses, bikes, and motorcycles caused the amount of steel and the consequent consumption of energy for its production to increase by approximately $18.23 \%$ ( $82.5 \%$ of which inside buses alone), having steel be a part of vehicles that are either less pollutant than cars or more efficient in terms of capacity or fuel caused steel's participation in annual emissions to decrease by $29.6 \%$, from 11.93 to $8.40 \mathrm{kgCO}$ eq $/ \mathrm{kg}$ of steel.

This increase in steel presence associated with lower participation in emissions highlights the importance of defining when and where to use steel, especially considering that the types of steel 
used for buses—typically UNS S30400, S31600, S40900 and S43000 [73]—are not necessarily considered specialty or complex alloys. It is to say that more steel can also be a solution, as long as it is used when and where necessary to support servitization and, further along, sustainability.

\section{Discussions and Conclusions}

This article used the criteria of sustainable urban metabolism and of circles of sustainability to analyze the contributions that three different case studies of servitization could provide to sustainable cities. Furthermore, the presence, contribution, and challenges regarding the steel within their servitization initiatives was evaluated.

Table 1 summarizes the results and discussions derived from analysis and evaluation, and serves to reinforce how useful all servitization case studies were towards improving eco-efficiency, resilience, sustainability, and self-sufficiency in the cities they were, or would be, deployed. All three case studies helped (a) lower dependency on external energy inputs, and (b) lower the output of emissions; even if at the expense of increasing local material stocks.

Table 1. Summary of results and discussions.

\begin{tabular}{|c|c|c|c|c|c|}
\hline \multirow{2}{*}{ Case Study } & \multicolumn{2}{|c|}{ Main Servitization Contributions According To } & \multicolumn{3}{|c|}{ Steel's } \\
\hline & $\begin{array}{l}\text { Sustainable Urban } \\
\text { Metabolism }\end{array}$ & $\begin{array}{c}\text { Circles of } \\
\text { Sustainability }\end{array}$ & Presence & Contribution & Challenge \\
\hline Energy & $\begin{array}{l}\text { - } \quad \begin{array}{l}\text { Lower external } \\
\text { energy inputs; }\end{array} \\
\text { Increased energy } \\
\text { circularity and flow } \\
\text { within boundaries; } \\
\text { - } \quad \text { Higher material } \\
\text { stocks } \\
\text { within boundaries; } \\
\text { Lower } \\
\text { emissions outputs. }\end{array}$ & 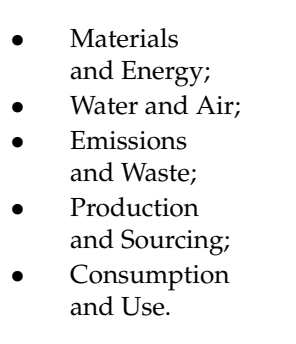 & Decreased & $\begin{array}{l}\text { Less steel in the right } \\
\text { places can help } \\
\text { create more } \\
\text { environmental value. }\end{array}$ & $\begin{array}{l}\text { HOW MUCH } \\
\text { steel to use, } \\
\text { WHERE to use } \\
\text { steel. }\end{array}$ \\
\hline Housing & $\begin{array}{ll}\text { - } & \text { Lower } \\
\text { inputs overall; } \\
\text { - } \\
\text { Higher stocks and } \\
\text { flows of food and } \\
\text { materials } \\
\text { within boundaries; } \\
\text { Lower } \\
\text { emissions outputs. }\end{array}$ & 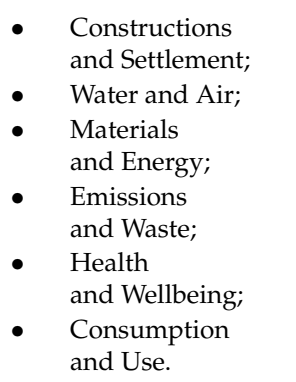 & Steady & $\begin{array}{l}\text { Different alloys used } \\
\text { to the best of their } \\
\text { potential can support } \\
\text { other goods' and } \\
\text { services' } \\
\text { environmental } \\
\text { values. }\end{array}$ & $\begin{array}{l}\text { WHAT type of } \\
\text { steel to use, } \\
\text { HOW to use } \\
\text { steel optimally. }\end{array}$ \\
\hline Mobility & 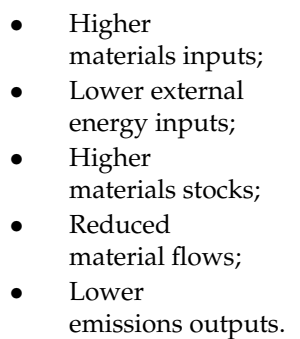 & $\begin{array}{ll}\text { - } & \text { Water and Air; } \\
\text { - } & \text { Emissions } \\
\text { - } & \text { Labor Waste; } \\
\text { - } & \text { Wealth } \\
\text { - } & \text { and Distribution; } \\
\text { Health } \\
\text { and Wellbeing. }\end{array}$ & Increased & $\begin{array}{l}\text { Regardless of } \\
\text { quantity, optimal } \\
\text { applications of even } \\
\text { the simplest of steel } \\
\text { alloys can help } \\
\text { improve the } \\
\text { environmental } \\
\text { values of a service or } \\
\text { good. }\end{array}$ & $\begin{array}{l}\text { WHEN and } \\
\text { WHERE to use } \\
\text { steel. }\end{array}$ \\
\hline
\end{tabular}

In the case of energy, deploying photovoltaic solar panels onto the roofs of houses significantly changed how energy is produced and consumed. When analyzing the case of housing, creating gardens and switching to eco-efficient appliances had substantial positive impact on health, wellbeing, and waste generation. Additionally, on what concerned mobility, a combined set of social and infrastructural measures has been proven capable of not only considerably reducing emissions, but also of stimulating job creation. 
When evaluating steel's behavior, each case study provided a unique insight. In the first case, steel's presence decreased, but its contribution to electricity generation and emission reduction was improved. In the second case, steel's presence was virtually unaltered, but the way it was used highlighted the potential for supporting a servitization initiative's environmental values. And in the third case, steel's presence increased only where and when it was more capable of contributing to the environmental goals at hand, even to the point of compensating increased energy consumption for its production.

These differences bring to light the importance that steelmakers also pay close attention to service-providing projects involving their clients and their products, since it was noticed that servitization is capable of altering steel demand in terms of quantity, but also quality and specialization requirements. The effects of servitization on the demand-side can change supply-side dynamics as well, creating both challenges and opportunities for steelmakers.

Considering that steel has a structural role in solar panels, as opposed to a direct operational one as in hydropower plants, not only does the amount of necessary steel change, but also where it is used, potentially requiring a steelmaker to consider migrating to new and upcoming markets. When it comes to eco-efficient appliances, specialized types of alloys and how they help the product improve efficiency play a bigger role than its quantity, a situation in which close collaboration with a client's development cycle might favor the steelmaker as well. And even if at the expense of short-term energy consumption and emissions increase, directing more production and technology development efforts towards steel alloys for vehicles which have environmentally friendlier characteristics can pose as an opportunity for portfolio expansion, market share capture and long-term environmental sustainability. Furthermore, all of these results would contribute even more to the overall environmental performance of the global steel industry, and for it to support the achievement of SDG goals if associated with a transition toward fossil-free production processes.

When addressing services, notably those with environmental purposes, most research as of the publication of this article focus on the operation, feasibility, and impacts of the proposed solution, and not on the holistic and systemic effects that feed back to the supply-side of the materials they replace, reduce, or displace. In addition, although different tools can be used to analyze and evaluate the benefits that servitization can provide to a sustainable city, more research is needed on the effects that servitization and other service-providing practices have on the commodities that flow through and within a city as a consequence of their implementation.

Author Contributions: Conceptualization, J.T.M.P; methodology, J.T.M.P, M.M, and A.D; formal analysis, A.D; investigation, J.T.M.P, M.M, M.K, and M.F; resources, J.T.M.P, M.M, M.K, and M.F; writing-original draft, J.T.M.P; review and editing, J.T.M.P and A.D; supervision, A.D; project administration, A.D; funding acquisition, A.D.

Funding: Marie Skłodowska Curie Fellowship Action in Excellent Research, European Commission's Horizon 2020 Program Grant Agreement no. 675153.

Acknowledgments: This article is part of a series of publications aimed at helping to improve environmentally-oriented policy- and decision-making in the European steel industry, focusing on sustainable resource management. It was developed with the support of experts from the "European Symposium on Sustainable Development" - held in Clermont-Ferrand (France)—and derives from AdaptEconII's project \#4, part of the European Commission's Horizon 2020 Program.

Conflicts of Interest: The authors declare no conflicts of interest. The funders had no role in the design of the study; in the collection, analyses, or interpretation of data; in the writing of the manuscript, or in the decision to publish the results.

\section{References}

1. Mega, V. Towards European sustainable cities. Athens Cent. Ekistics 1996, 63, 273-288.

2. Akande, A.; Cabral, P.; Gomes, P.; Casteleyn, S. The Lisbon ranking for smart sustainable cities in Europe. Sustain. Cities Soc. 2019, 44, 475-487. [CrossRef]

3. Bibri, S.E.; Krogstie, J. Smart sustainable cities of the future: An extensive interdisciplinary literature review. Sustain. Cities Soc. 2017, 31, 183-212. [CrossRef] 
4. Albertí, J.; Balaguera, A.; Brodhag, C.; Fullana-I-Palmer, P. Towards life cycle sustainability assessment of cities. A review of background knowledge. Sci. Total Environ. 2017, 609, 1049-1063. [CrossRef] [PubMed]

5. Ahvenniemi, H.; Huovila, A.; Pinto-Seppä, I.; Airaksinen, M. What are the differences between sustainable and smart cities? Cities 2017, 60, 234-245. [CrossRef]

6. Green, M.H.; Davies, P.; Ng, I.C.L. Two strands of servitization: A thematic analysis of traditional and customer co-created servitization and future research directions. Int. J. Prod. Econ. 2017, 192, 40-53. [CrossRef]

7. Kohtamäki, M.; Baines, T.; Rabetino, R.; Bigdeli, A.Z. Practices and Tools for Servitization: Managing Service Transition; Palgrave Macmillan: Birmingham, UK, 2018; ISBN 9783319765167.

8. Kowalkowski, C.; Gebauer, H.; Oliva, R. Service growth in product firms: Past, present, and future. Ind. Mark. Manag. 2017, 60, 82-88. [CrossRef]

9. Tukker, A. Product services for a resource-efficient and circular economy-A review. J. Clean. Prod. 2015, 97, 76-91. [CrossRef]

10. Grober, U. Deep Roots-A Conceptual History of Sustainable Development; Wissenschaftszentrum Berlin für Sozialforschung (WZB): Berlin, Germany, 2007.

11. BC. Report of the World Commission on Environment and Development: Our Common Future; Brundtland, G.H.: Oslo, Norway, 1987.

12. Aalborg Charter. Charter of European Cities \& Towns towards Sustainability. In Proceedings of the European Conference on Sustainable Cities \& Towns, Aalborg, Denmark, 27 May 1994.

13. UNEP. Melbourne Principles for Sustainable Cities; United Nations Environment Programme-Division of Technology, Industry, and Economics-International Environmental Technology Center: Osaka, Japan, 2002.

14. Sartori, S.; Silva, F.L.; Campos, L.M.S. Sustainability and sustainable development: A taxonomy in the field of literature. Ambient. Soc. 2014, 17, 1-22. [CrossRef]

15. Meadows, D.L.; Meadows, D.H.; Randers, J. Beyond the Limits: Confronting Global Collapse, Envisioning a Sustainable Future; Green Publishing: Chelsea, MA, USA, 1993; ISBN 0930031628.

16. Brugmann, J. Welcome to the Urban Revolution: How Cities Are Changing the World; Bloomsburry Press: London, UK, 2009; ISBN 9781608190928.

17. Burdett, R.; Sudjic, D. Living in the Endless City; Phaidon Press: London, UK, 2011; ISBN 9780714861180.

18. Rogers, R. Cities for a Small Planet; Westview: Boulder, CO, USA, 1997; ISBN 0813335531.

19. De Jong, M.; Joss, S.; Schraven, D.; Zhan, C.; Weijnen, M. Sustainable-smart-resilient-low carbon-eco-knowledge cities; making sense of a multitude of concepts promoting sustainable urbanization. J. Clean. Prod. 2015, 109, 25-38. [CrossRef]

20. Lay, G. Servitization in Industry; Springer: Cham, Switzerland, 2014.

21. Levitt, T. The Marketing Mode_Pathways to Corporate Growth; McGraw-Hill: New York, NY, USA, 1969.

22. Vandermerwe, S.; Rada, J. Servitization of business: Adding value by adding services. Eur. Manag. J. 1988, 6, 314-324. [CrossRef]

23. Matschewsky, J.; Kambanou, M.L.; Sakao, T. Designing and providing integrated product-service systems-Challenges, opportunities and solutions resulting from prescriptive approaches in two industrial companies. Int. J. Prod. Res. 2017, 56, 2150-2168. [CrossRef]

24. Frambach, R.T.; Wels-Lips, I.; Gündlach, A. Proactive product service strategies-An application in the European health market. Ind. Mark. Manag. 1997, 26, 341-352. [CrossRef]

25. Boyt, T.; Harvey, M. Classification of industrial services-A model with strategic implications. Ind. Mark. Manag. 1997, 26, 291-300. [CrossRef]

26. Mathieu, V. Service strategies within the manufacturing sector: Benefits, costs and partnerships. Int. J. Serv. Ind. Manag. 2001, 12, 451-475. [CrossRef]

27. Tukker, A. Eight types of product-service system: Eight ways to sustainability? Experiences from Suspronet. Bus. Strategy Environ. 2004, 13, 246-260. [CrossRef]

28. Lightfoot, H.; Baines, T.; Smart, P. The servitization of manufacturing: A systematic literature review of interdependent trends. Int. J. Oper. Prod. Manag. 2013, 33, 1408-1434. [CrossRef]

29. Baines, T.S.; Lightfoot, H.W.; Benedettini, O.; Kay, J.M. The servitization of manufacturing: A review of literature and reflection on future challenges. J. Manuf. Technol. Manag. 2009, 20, 547-567. [CrossRef]

30. Coombs, R.; Miles, I. Innovation, Measurement and Services: The New Problematique; Kluwer Academics: Boston, MA, USA, 2000. 
31. Oliva, R.; Kallenberg, R. Managing the transition from products to services. Int. J. Serv. Ind. Manag. 2003, 14, 160-172. [CrossRef]

32. Zhang, W.; Banerji, S. Challenges of servitization: A systematic literature review. Ind. Mark. Manag. 2017, 65, 217-227. [CrossRef]

33. Burton, J.; Story, V.M.; Raddats, C.; Zolkiewski, J. Overcoming the challenges that hinder new service development by manufacturers with diverse services strategies. Int. J. Prod. Econ. 2017, 192, 29-39. [CrossRef]

34. Rothenberg, S. Sustainability through servicizing. MIT Sloan Manag. Rev. 2007, 48, 82-91.

35. World Steel (WS). Sustainable Steel: At the Core of a Green Economy; WorldSteel Association: Brussels, Belgium, 2012.

36. World Steel (WS). World Steel in Figures 2018; WorldSteel Association: Brussels, Belgium, 2019; Available online: https:/ / www.worldsteel.org/media-centre/press-releases/2018/world-steel-in-figures-2018.html (accessed on 18 January 2019).

37. Beddows, R. Steel 2050-How Steel Transformed the World and Now Must Transform Itself; Devonian: Kingsbridge, UK, 2014; ISBN 0993038107.

38. Olmez, G.M.; Dilek, F.B.; Karanfil, T.; Yetis, U. The environmental impacts of iron and steel industry: A life cycle assessment study. J. Clean. Prod. 2015, 130, 195-201. [CrossRef]

39. Vaclav, S. Still the Iron Age; Butterworth-Heinemann, Elsevier: Oxford, UK, 2016; ISBN 9780128042359.

40. Warrian, P. A Profile of the Steel Industry-Global Reinvention for a New Economy; Business Expert Press: New York, NY, USA, 2012; ISBN 1631573845.

41. OECD. Eco-Innovation in Industry: Enabling Green Growth; Organisation for Economic Co-Operation and Development: Paris, France, 2010; ISBN 9789264077218.

42. IEA. Iron and Steel: Tracking Clean Energy Progress. International Energy Agency. 2018. Available online: https: / / www.iea.org/tcep/industry/steel/ (accessed on 18 January 2019).

43. EC. Communication from the Commission to the Parliament, the Council, the European Economic and Social Committee and the Committee of Regions: Action Plan for a Competitive and Sustainable Steel Industry in Europe. COM(2013) 407; European Commission: Strasbourg, France, 2013; Available online: https: / / eur-lex.europa.eu/legalcontent/EN/TXT/?uri=celex\%3A52013DC0407 (accessed on 16 January 2019).

44. WS. Steel, the Permanent Material in the Circular Economy; WorldSteel Association: Brussels, Belgium, 2016.

45. BIR. World Steel Recycling in Figures; Bureau of International Recycling: Brussels, Belgium, 2017.

46. Eurofer. Steel, the Backbone of Sustainability in Europe; The European Steel Association, Eurofer: Brussels, Belgium, 2017.

47. Centre for European Policy Studies (CEPS). Assessment of Cumulative Cost Impact for the Steel Industry; CEPS: Brussels, Belgium, 2013.

48. IETD. Electric Arc Furnaces Technologies \& Measures. Institute for Industrial Productivity-Industrial Efficiency Technology Database, 2018. Available online: http:/ / ietd.iipnetwork.org/content/electric-arcfurnace (accessed on 5 May 2018).

49. Waugh, R. The end of the blast furnace era? Ironmak. Steelmak. 2016, 258-263. [CrossRef]

50. Material Economics. The Circular Economy-A Powerful Force for Climate Mitigation; Material Economics: Stockholm, Sweden, 2018.

51. Graedel, T.E.; Allenby, B.R. Industrial Ecology; Prentice Hall: Englewood Cliffs, NJ, USA, 1995.

52. James, P. Circles of Sustainability; Routledge: Abingdon-on-Thames, UK, 2015.

53. Petit-Boix, A.; Llorach-Massana, P.; Sanjuan-Delmás, D.; Sierra-Pérez, J.; Vinyes, E.; Gabarrell, X.; Rieradevall, J.; Sanyé-Mengual, E. Application of life cycle thinking towards sustainable cities: A review. J. Clean. Prod. 2017, 166, 939-951. [CrossRef]

54. Ferrao, P.; Fernandez, J.E. Sustainable Urban Metabolism; MIT Press: Cambridge, MA, USA, 2013; ISBN 9780262019361.

55. CoS. Circles of Sustainability-Practical Tools for Creating Sustainable Cities and Communities. 2018. Available online: https:/ / www.circlesofsustainability.org/cities/ (accessed on 5 May 2018).

56. Pinto, J.T.M.; Amaral, K.J.; Janissek, P.R. Deployment of photovoltaics in Brazil: Scenarios, perspectives and policies for low-income housing. Sol. Energy 2016, 133, 73-84. [CrossRef] 
57. Cerón-Palma, I.; Sanyé-Mengual, E.; Oliver-Solà, J.; Montero, J.-I.; Ponce-Caballero, C.; Rieradevall, J. Towards a green sustainable strategy for social neighborhoods in Latin America: Case from social housing in Merida, Yucatan, Mexico. Habitat Int. 2013, 38, 47-56. [CrossRef]

58. Diez, J.M.; Lopez-Lambas, M.E.; Gonzalo, H.; Rojo, M.; Garcia-Martinez, A. Methodology for assessing the cost effectiveness of Sustainable Urban Mobility Plans (SUMPs). The case of the city of Burgos. J. Transp. Geogr. 2018, 68, 22-30. [CrossRef]

59. Sorrell, S. The Economics of Energy Service Contracts. Energy Policy 2007, 35, 507-521. [CrossRef]

60. Neely, A. Servitization in Germany: An International Comparison; Cambridge Service Alliance: Cambridge, UK, 2013.

61. Neely, A. Exploring the Financial Consequences of the Servitization of Manufacturing. Oper. Manag. Res. 2008, 1, 103-118. [CrossRef]

62. Benedetti, M.; Cesarotti, V.; Holgado, M.; Introna, V.; Macchi, M. A Proposal for Energy Services' Classification Including a Product Service Systems Perspective. Procedia CIRP 2015, 30, 251-256. [CrossRef]

63. Hamwi, M.; Lizarralde, I.; Legardeur, J.; Technopole, I.; Birdart, F. Energy Product Service Systems as Core Element of Energy Transition in the Household Sector: The Greenplay Project. In Proceedings of the 22nd International Sustainable Development Research Society Conference, Lisbon, Portugal, 13-15 July 2016.

64. Polzin, F.; von Flotow, P.; Nolden, C. Exploring the Role of Servitization to Overcome Barriers for Innovative Energy Efficiency Technologies-The Case of Public LED Street Lighting in German Municipalities; SWPS; University of Sussex: Brighton, UK, 2015.

65. IEA. Projections: Energy Policies of IEA Countries Online Data Service. International Energy Agency, 2017. Available online: https://www.iea.org/classicstats/relateddatabases/ projectionsenergypoliciesofieacountries/ (accessed on 21 April 2018).

66. Koch-Orvad, N.; Thuesen, C. Sustainable Building in Scandinavia: Directions of Innovations for Supporting the Transition. In Proceedings of the 32nd Annual ARCOM Conference, Manchester, UK, 5-7 September 2016.

67. Kibert, C.J. Green buildings: An overview of progress. J. Land Use Environ. Law 2003, 19, 491-502.

68. Wu, M.H.; Ng, T.S.; Skitmore, M.R. Sustainable building envelope design by considering energy cost and occupant satisfaction. Energy Sustain. Dev. 2016, 31, 118-129. [CrossRef]

69. LEED. Reference Guide for Green Building Design and Construction; U.S. Green Building Council: Washington, DC, USA, 2010.

70. WEC. World Energy Trilemma Index; World Energy Council: London, UK, 2018.

71. Petros-Sebhatu, S.; Enquist, B. Sustainable Public Transit Service Value Network for Building Living Cities in Emerging Economies: Multiple Case Studies from Public Transit Services. Soc. Behav. Sci. 2016, 224, 263-268. [CrossRef]

72. Cerfontaine, C. Combined mobility: Public transport in synergy with car-sharing, cycling, taxis, etc., a smart way forward. In Proceedings of the 5th UITP Combined Mobility Workshop, Hannover, Germany, 20 October 2014 ; p. 30.

73. Bringas, J.E. Handbook of Comparative World Steel Standards; ASTM International: West Conshohocken, PA, USA, 2004; ISBN 0803133626.

74. Greiner, R. High strength steels for hydropower plants-A conference bringing together specialists from many disciplines. Steel Constr. Des. Res. 2013, 6, 247-248. [CrossRef]

75. ANEEL. Atlas de Energia Elétrica do Brasil; Agência Nacional de Energia Elétrica: Brasilia, Brazil, 2009.

76. Souliotis, M.; Arnaoutakis, N.; Panaras, G.; Kavga, A.; Papaefthimiou, S. Experimental study and Life Cycle Assessment (LCA) of Hybrid Photovoltaic/Thermal (PV/T) solar systems for domestic applications. Renew. Energy 2018, 126, 708-723. [CrossRef]

77. International Stainless Steel Forum (ISSF). Stainless Steel in Solar Energy Use; International Stainless Steel Forum: Brussels, Belgium, 2015; ISBN 978-2-930069-53-1.

78. Bracquene, E.; Peeters, J.R.; Dewulf, W.; Duflou, J.R. Taking Evolution into Account in a Parametric LCA Model for PV Panels. Procedia CIRP 2018, 69, 389-394. [CrossRef]

79. Hasanbeigi, A.; Price, L.; Aden, N.; Chunxia, Z.; Xiuping, L.; Fangqin, S. Comparison of Iron and Steel Production Energy Use and Energy Intensity in China and the U.S.; Berkeley National Laboratory, U.S. Department of Energy: Washington, DC, USA, 2011. 
80. van Schaik, A.; Reuter, M.A. Dynamic modelling of E-waste recycling system performance based on product design. Miner. Eng. 2010, 23, 192-210. [CrossRef]

81. Oguchi, M.; Murakami, S.; Sakanakura, H.; Kida, A.; Kameya, T. A preliminary categorization of end-of-life electrical and electronic equipment as secondary metal resources. Waste Manag. 2011, 31, 2150-2160. [CrossRef]

82. ECO3E. Eco-Design Guide of WEEE Compliance Schemes. Product Database. 2018. Available online: http: / / eco3e.eu/en/ressources / eco-products / (accessed on 28 September 2018).

83. ADEME. Global Inventories of the Worldwide Fleets of Refrigerating and Air-Conditioning Equipment in Order to Determine Refrigerant Emissions; French Agency for the Environment and Energy Management (ADEME): Paris, France, 2010.

84. ÖKO. Eco-Efficiency Analysis of Washing machines; Commissioned by the European Committee of Domestic Equipment Manufacturers (CECED), Öko-Institut e.v.: Freiburg, Germany, 2005.

85. Kärnä, P. Carbon Footprint of the Raw Materials of an Urban Transit Bus-Case Study: Diesel, Hybrid, Electric and Converted Electric Bus; Lahti University of Applied Sciences, Programme in Environmental Technology: Lahti, Finland, 2012.

86. Leuenberger, M.; Frischknecht, R. Life Cycle Assessment of Two Wheel Vehicles; ESU-Services Ltd.: Uster, Switzerland, 2010.

87. WS. Steel in Automotive; WorldSteel Association: Brussels, Belgium, 2018; Available online: https://www. worldsteel.org/steel-by-topic/steel-markets/automotive.html (accessed on 28 September 2018).

(C) 2019 by the authors. Licensee MDPI, Basel, Switzerland. This article is an open access article distributed under the terms and conditions of the Creative Commons Attribution (CC BY) license (http:/ / creativecommons.org/licenses/by/4.0/). 